\title{
THE SOILS OF THE PARQUE NATURAL DA ARRÁBIDA
}

\author{
ROLF SCHRITTENLOCHER ${ }^{1}$
}

\begin{abstract}
The soils of the Parque Natural da Arrábida are surveyed along four catenae right across the Parque. Dominant soil formating processes and their regional importance are shown.The soils are described as units according to FAO (1988). On the basis of the FAO units an attempt is made to combine soil units with ecological classes. A comparison with the soil map 38-B and the Portuguese classification (Cardoso 1964) is given. Unfortunately it is not possible to transform the units of that map into soil units according to FAO (1988).
\end{abstract}

Key-words: Parque Natural da Arrábida, soil, FAO.

Resumo - Os Solos do Parque Natural da ArRÁbida - Os solos do Parque Natural da Arrábida foram estudados ao longo de quatro transectos. Descrevem-se os principais processos de formação dos solos e a sua importância regional. Os solos são descritos como unidades, seguindo a classificação da FAO de 1988. Com base nestas unidades, tenta-se agrupar as unidades pedológicas em classes ecológicas. É levada a cabo uma comparação com a folha 38-B da Carta de Solos de Portugal, não sendo infelizmente possível elaborar uma chave com a correspondência entre as duas classificações.

Palavras-chave: Parque Natural da Arrábida, solos, FAO.

\section{I - INTRODUCTION}

The objectives of the soil survey discussed here were to provide the projects concerned with Arrábida and other scientists working in the area with basic pedological data. Furthermore, it intended to find possible approaches to the already existing soil map (SROA, 1969) which has limited utility for reasons to be discussed here. Other results concerning the relations between soil units and plant units, the endangering of soil functions by erosion, immissions, etc., and the protection of the soils are part of the thesis of the author which may be consulted at the Centro de Estudos Geográficos, Faculdade de Letras, Universidade de Lisboa.

${ }^{1}$ Investigador da Universidade de Marburg, c/o Prof Dr. W. Endlicher, FB Geographie Philipps-Universität Marburg, Deutschhausstr. 10, D-35032 Marburg, Germany 


\section{II - METHODS}

The Parque totals 10.821 hectars. Since this expanse is too big for an overall survey, the catena princip was chosen. Two catenae were laid between the coast and the northern boundary of the Parque; one from Formosinho and Alto da Madalena to Vila Nogueira de Azeitão, the other one runs from Arremula and Cuco to Vila Fresca de Azeitão. Two others are situated in the east and the west, one starting from Terras do Risco and ending north of Alto das Vinhas, the other running from Serra do São Luís to Quinta do Anjo (fig. 1).

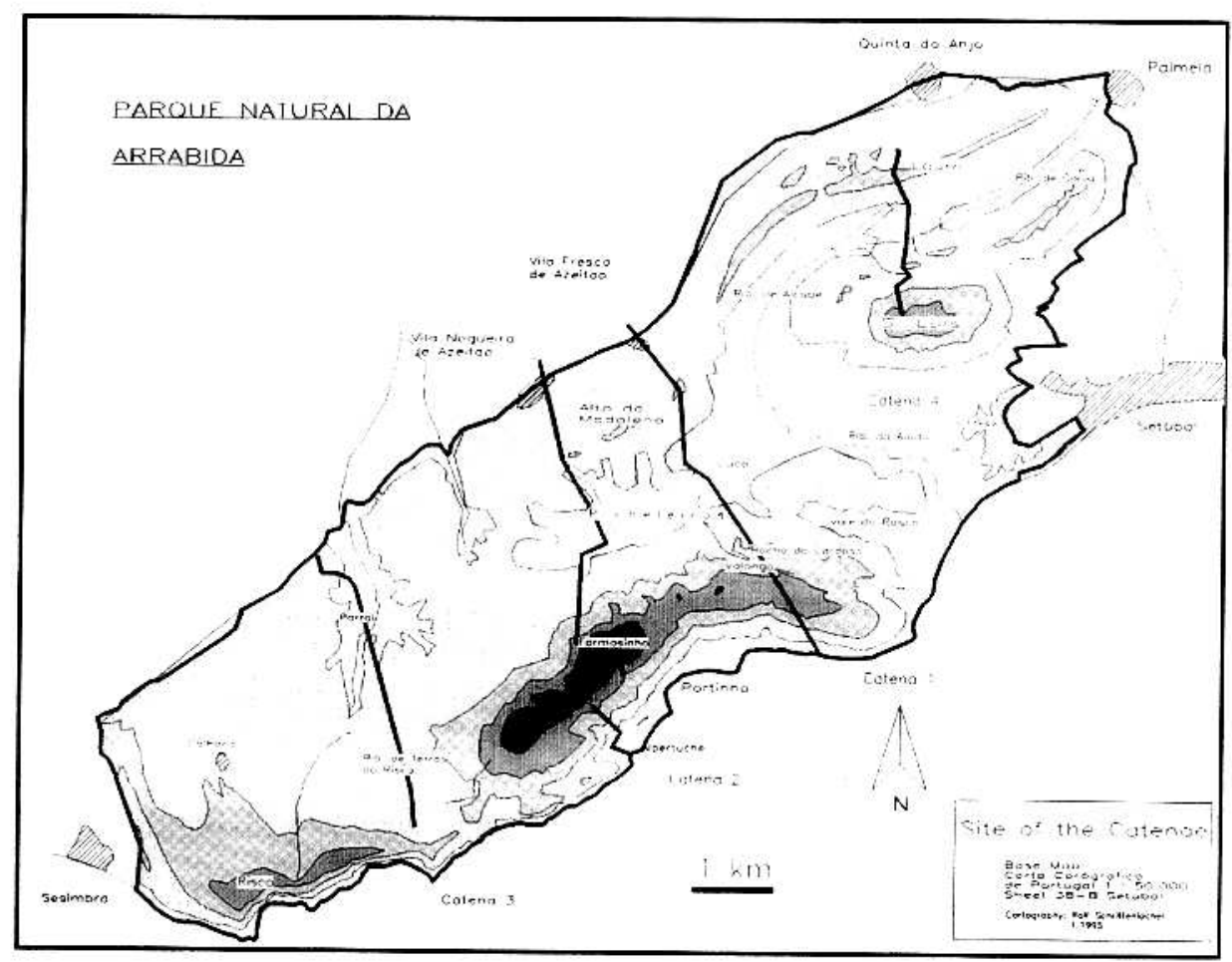

Fig. 1 - Site of the Catenae

Fig. 1 - Localização dos transectos

At an average distance of 50m location, lithology, relief, exposition and type of vegetation were recorded (fig. 2). By drilling with a hand operated gouge auger (Pürckhauer type) of $1 \mathrm{~m}$ in length and $3 \mathrm{~cm}$ in diameter, soil type horizon and strata boundaries, and hydromorphic features (concretions) were noted. Soil texture was determined by the finger method, and colours were determined by the Munsell colour chart. Texture units follow the FAO classification (FAO, 1974/1988, s. table 2.1), detailed particle size distribution in profiles correspond to the German 
system (AG BODENKUNDE, 1982). This differentiation was necessary because the FAO classes are obviously too broad for many problems. All other data were checked for plausibility and obvious errors by analyses. $\mathrm{CaCO}_{3}$ content was estimated semiquantitatively with hydrochloric acid (AG BODENKUNDE, 1982), quality of the organic matter as well as stoniness were recorded (AG BODENKUNDE, 1982). The available water capacity at the potential rooting depth (AWCr) was estimated in pits and at road cuts by a field method comprising texture, structure, density, stability and resistance to penetration, proportion of macropores, actual rooting depth and distribution of roots (HARRACH, 1990).

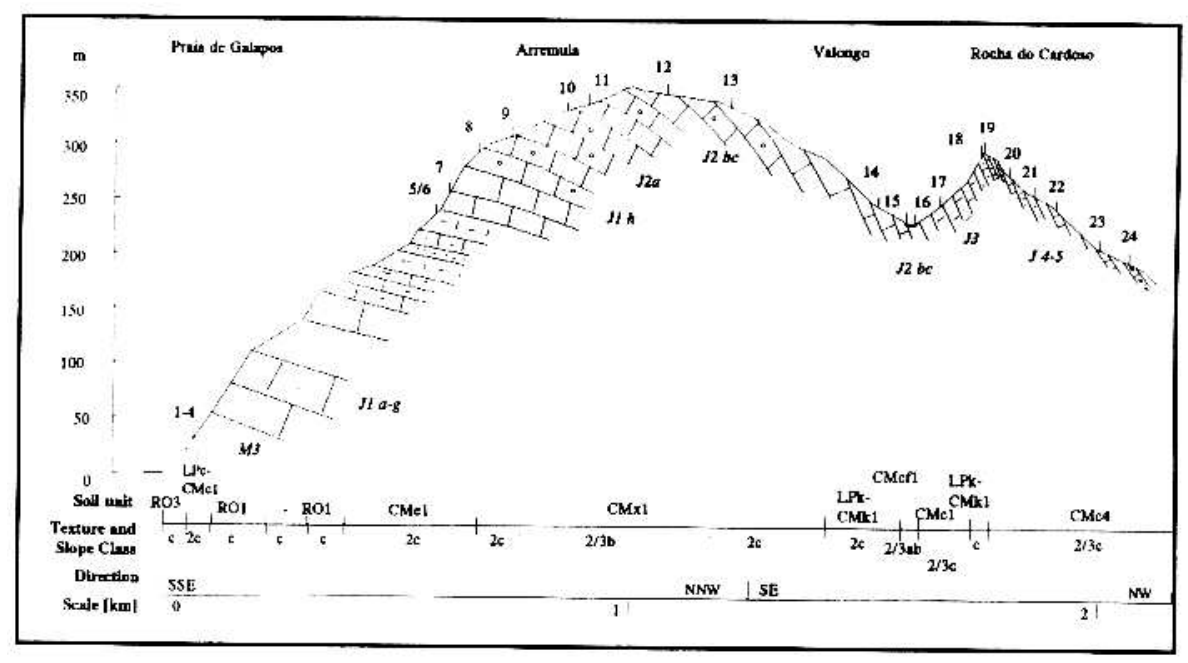

Fig. 2 - Southern Part of Catena 1

Fig. 2 - Extremo sul do transecto 1

Soil samples were taken for further investigation and analysed in the laboratory for $\mathrm{pH}(\mathrm{KCl})$ according to FAO (1988). Cation exchange capacity (CEC), extractable acidity and base saturation product (BSP) were determined where necessary by the method of KAPPEN (1928) and exchangeable cations by the AAS. Field data for particle size distribution were certified by chosen samples by the pipette method (DIN, 1973).

In agreement with the project partners the FAO classification (FAO, 1974/1988) was chosen. The reasons are the widespread international use of this classification, the easier accessibility for nonpedologists compared to the Portuguese classification or the US soil taxonomy, and the fact that new soil maps published in Portugal are using the FAO classification as well.

Since the FAO classification was established for the world soil map at a scale 
of 1: 5000000 and the field work here was carried out at a scale of 1: 10000 , certain supplements had to be made. Firstly a few definitions had to be amended or enlarged. Secondly additional units had to be established. The former is inflicted by the information limits of large scale maps and by some inconsistency of FAO definitions. The latter is justified by the FAO legend (1988) if the original definitions are newly combined and definitions remain clear and do not overlap. Where necessary, enlarged or new definitions are shown in the text in italics. Some units were taken as defined for the Soil Map of the European Communities (1985).

\section{III - REGIONAL IMPORTANCE OF SOIL FORMATION PROCESSES}

Knowing the present and previous soil formation processes in the area helps to understand the recent distribution pattern. The present pedological conditions can partly be estimated if the situation of other factors and the soil forming processes dominant for the place are known. The most important factors are climate, geology and tectonics, relief, vegetation, and human impact. The author will refer to these factors here only where they are actually of great importance. A detailed description is given by PEDRO (1991) and RIBEIRO (1968).

\section{Rubification and Verbraunung}

Rubification is not the most important process occuring or having occured in the soils of Arrábida. But as it is one of the most widely discussed processes, and one reason for the pedological speciality of the region, it is mentioned here first. The red colours of many soils are widespread at Arrábida on calcareous or dolomitic bedrock from the coastal line to the north all over the early and middle Jurassic and most of the late Jurassic as well. Red colours of the non or very weakly calcareous conglomerates of the late Jurassic and the Cretaceous result from the colour of the parent material. On the Oligocene and Miocene layers intensive red colours can seldom be seen, due to erosion at the Oligocene cuesta in the north of the Parque and the cultivation and deep ploughing of its softly inclined northern slope.

There are still different opinions about the development of these red soils, commonly known as "Terra Rossa" or "Red Mediterranean Soils" in Europe. An overview of this problem is given, e.g. in CARDOSO (1965, pp. 145f.) and SKOWRONEK (1978). It seems to be common agreement that these soils develop or have developed under a climate with high soil temperature and accentuated arid and humid phases from the residuals of limestone and similar bedrock by rubification during and after decarbonization (SKOWRONEK, 1978 100f.). The formation of the Red Mediterranean Soils might take place either with intermediate stages like the Rendzina (KUBIENA, 1953) or also directly (SKOWRONEK, 1978, pp. 116f.). Contrary to many authors' opinions, CARDOSO (1965, p.126) states that these "Solos Mediterrâneos Vermelhos de Materiais 
Calcários" do not only develop on hard and pure limestone or dolomite, but also on unconsolidated calcareous material and calcareous sandstone or calcareous conglomerate. This thesis was confirmed by the fieldwork. As the target of this survey was not soil genesis, it has not been investigated whether this is only a relict process or it is still going on today. But there are signs which indicate that it is continuing today at an unknown rate.

Verbraunung is going on in almost all soils today due to the annual precipitation of 600-700 $\mathrm{mm}$ (stations of Sesimbra and Setúbal). It is always combined with formation of secondary silicates which, in its most intensive form, leads to the clayey soils of yellowish colours ("terra fusca / Braunlehm" of KUBIENA, 1953) on the limestone of the middle Jurassic south of Terras do Risco. Probably the lower relief intensity and the less inclined geological layers resulted in a higher soil humidity and finally in the formation of Goethite instead of Hematite. In the surveyed area this material was found colluviated and partly recalcified in the basin of Terras do Risco. Soils of intensive colours are named after FAO (1974) chromic, the red hue is marked as rhodic phase.

Today all Red Mediterranean Soils are subject to clay migration (CARDOSO, 1964, p.520) which includes them in the FAO classification as Rhodo-Chromic Luvisols (LVx rhod) with an A/E/Bt/C profile. These soils, although presented in the Portuguese soil map (SROA, 1969) in a big area, are very rare today because they are generally eroded and included either in Rhodo-Chromic Cambisols (CMx rhod) or in Rhodo-Calcaric Cambisols (CMc rhod) ${ }^{1}$.

\section{Decarbonization}

As many of Arrábida's soils have developed on calcareous parent material, decarbonization is one of the first soil formation processes to happen. The Rhodo-Chromic Luvisols and Cambisols were totally decarbonized, but today, due to erosion and mixing with calcareous material, Rhodo-Calcaric Cambisols are common in steep reliefs and at the footslopes. Many soils from colluviated materials show some loss of free carbonates in the topsoil again (fig. 5).

North of Arrábida's main ridge decarbonization progressed further. In the west with its gently undulating relief, remixing with carbonatic material was more seldom throughout the area the lithology supports that process. The bedrock of the late Jurassic contains less carbonates and is usually coarse textured, resulting in an easy exchange of the soil water solution saturated with carbonates.

The Tertiary has mainly calcareous facies again and the Tertiary cuesta shows a situation similar to the southern Serras. On the slopes decalcified soils were eroded and partly recarbonized, often covering the relict soil situated below. Especially on the northern slope agricultural use with ploughing usually brings free carbonates to the topsoils again.

${ }^{1}$ For the supplemented definition of "Cambisols" see chapter IV.3. 
All soils that lose carbonates in the upper horizons show some $\mathrm{CaCO}_{3}$ enrichment in the subsoil. Sometimes but not always this can be seen in the profile as a Bck or Ck horizon. Decalcified soils generally belong to the unit of eutric soils (FAO, 1974).

Today, at least in the Western part, soils are being enriched with carbonates again. They stem from dust from the roads or are aeolic deposits from the quarries (SCHRITTENLOCHER, 1995). The soils near Outão contain aeolic deposits from the quarries and the cement industry located there.

\section{Clay Migration}

In chapter III.1 the clay migration was already mentioned for the Chromic Luvisols. Clay migration is an ongoing process important for the soils especially in the western half of the Parque, in the valley between the main Jurassic and the Tertiary ridge. If the bedrock contains carbonates, the decarbonization of the soils is required before eluviation can take place. It can be seen at Pliocene/Pleistocene sands showing clay lamellae. It is more important in the western region near Calhariz on calcareous sandstones and conglomerates. Soils having an argillic horizon from clay illuviation are defined as luvic soils or Luvisols according to the FAO (1988).

Clay migration has been a factor for erosion, too. The surface horizons, which are poor in clay contents and relatively enriched with silt, are more easily erodable. Consequently, silt is the dominant fraction in most colluvia and Fluvisols.

\section{Podzolization}

Podzolization is widespread on the Pliocene/Pleistocene sands of the Tagus basin neighbouring the surveyed region. The small areas with these sands in the Parque are only podzolized where they have a certain thickness. In general the underlying layer is calcareous material from the Tertiary, which influences the upper horizon to a certain degree by capillary ascent. Therefore, the soils on Pliocene/Pleistocene sands at Portela da Sardinha and close to Alto das Vinhas show only some symptoms of an initial podzolization. The Pliocene/Pleistocene sands north of Ribeira de Terras do Risco are podzolized if they are not colluviated (see III.5). Some Luvisols in this area show podzolic features as well. The Podzols are also influenced by the aeolic deposits described in III.2.

\section{Erosion and Colluviation}

The combination of these two factors dominates soil development in most 
parts of the Parque and covers up the results of other processes. There are more soils colluviated or developed on colluvium than in situ. Colluvium must here be seen not only as topsoil material with an appreciable amount of organic matter, but very often as translocated B or C material with little or no organic matter (an exception are some rendzic soils). Soil profiles show that a period, when decarbonization, rubification, Goethite formation, clay formation and migration were the most important soil forming processes, was followed by one or perhaps several periods, during which erosion and colluviation were dominant. This was probably due to destruction of the vegetation by fires. Today it seems that around the main ridge there is a certain stability again. Zones extremely affected by erosion today are located in the hills between the Jurassic mountain ridge and the Tertiary cuesta. There clearings, terracing, improper road construction, agriculture, pasture and, last but not least, fires have accelerated erosion in some places to a high degree.

These translocations greatly complicate the soil survey and pedological description, because they are unevenly spread. With a boring depth of one meter it is often impossible to say if the material found at a place lies in situ or has been colluviated. The soils found are in general polygenetic e.g. Rhodo-Calcaric Cambisols derived mainly from soils which were decarbonated and rubified, later clay in the topsoil was eluviated and then the soil was eroded. If the argillic horizon was eroded too, the clay suspended in water and the red silty soil material, mixed with calcareous material during transport, were accumulated over some distance.

Accelerated erosion is restricted to a landscape with greatly damaged or destroyed vegetation. Places like the steep southern slope of Alto da Madalena with an average of more than 20 inclination show that under dense vegetation (this area being a seminatural pine forest), erosion only takes place at a low degree. The same was observed during a week of excessive rainfall in May 1994 in Mata de Solitario. Only the litter was partly affected by flowing water on the soil surface. On the other hand a slope with 16 south of Serra do Louro was eroded to a depth of about $50 \mathrm{~cm}$. Farmers there said that the slope had been cleared two years before.

A special case are the colluvia of the Pliocene/Pleistocene sands near Parral and along the northern border of the Parque which contain about 2-4\% organic matter throughout the profile. They are a result of longterm agricultural use, erosion by water and especially by wind, and because of their features they are described as Aric Arenosols.

\author{
6. Cultivation
}


Cultivation and soil treatment for agricultural purpose have, apart from the hazards of erosion, the strongest effect on soils in a short time. Ploughing leads to an Ap instead of a Ah horizon. Deep ploughing up to one meter is common especially in vineyards, there the $\mathrm{B}$ and sometimes $\mathrm{C}$ horizons are also concerned. The results of terracing are similar. Formerly land was terraced in order to plant corktrees, whereas today it is done to facilitate construction. In some cases pasture land has been ploughed to destroy the shrub and provide a better pasture for livestock.

\section{Surface and Groundwater Influence}

Surface water influence is named stagnic phase by the FAO. It is seldom found and restricted to an almost flat relief. Water saturation results either from a less permeable argillic horizon, which is the case with some Luvisols near Calhariz in the west, or from a less permeable geological stratum, which is the case especially with some Pliocene/Pleistocene sands.

Very often stagnic features occur together with gleyic characteristics, resulting from subsurface water or an aquifer close to the surface, and cannot clearly be differentiated from the latter. Water saturation usually occurs only from late autumn to spring. As mainly flowing water containing oxygen is involved, oxidation marks dominate over reduction marks.

Gleyic features occur like stagnic ones in Pliocene/Pleistocene sands on less permeable layers; they become increasingly more frequent to the east at the Oligocene cuesta, first only on the southern slope, later at the northern, too. Soils influenced by groundwater at a shallow depth (Gleysols, some Gleyic Arenosols) are restricted to a few spots with springs at Serra do Louro and to an area near Ribeira de Terras do Risco.

\section{Accumulation of Organic Matter}

Under dense vegetation organic matter accumulates for various reasons. For the Podzols it is partly the quality of the litter which prevents a fast destruction by the microorganisms and leads to the self-increasing process of acidification and podzolization.

On limestone chemical conditions are favourable and the litter of plants growing there is usually well degradable. There, in general, the organic matter is accumulated in a stable form as Ca-Humate in the rendzic soils. The thickness of a rendzic topsoil might by enlarged by colluviation which is the case for some rendzic soils in the late Jurassic layers at Formosinho's northern slope.

Where there is a lack of water for biological activities, sometimes a mighty

2 The J3 signature on the geological map (SG 1964) corresponds to the Oxfordian according to LEINFELDER (1983). 
organic layer covers the mollic A horizon of rendzic soils. This is the case e.g. with the talus debris at the transition from middle to late Jurassic (J2 to J3) on the northern slope of Arrábida and in the valley of São João do Deserto.

\section{IV - THE SOIL UNITS OF THE PARQUE NATURAL DA ARRÁBIDA}

Soils surveyed along the four catenae are summarized in units and described below. Soil units in an inhomogenous area like the Parque Natural da Arrábida consist of various elements. The unit goes by the name of the dominant soil, the main qualities of its soils are described in the legend specified in this chapter. The unit generally includes associated soils. Units which can be found at a singular spot only and to a small extent are neglected.

The soil units are given in an order according to their content of free carbonates and their base saturation status. This has to be understood as just a guideline. Soils of very different chemical and physical properties are sometimes closely associated and mentioned in one unit although they could be integrated in different groups. The aspect of aeolic deposits complicates the situation whenever samples of formerly dystric soils show a high BSP and an increased $\mathrm{pH}$ in the topsoil. According to the FAO these soils, with the exception of the Podzols, are defined as eutric soils; here they are grouped under coarse textured eutric soils.

\section{Miscellaneous Land - Rock Outcrop}

No soil in the narrower sense, but hard rock sometimes with initial soil development and associated with small patches of soils. Shown at the FAO as miscellaneous land.

RO1: Rock Outcrop of limestone, dolomite, calcareous sandstone or siltstone or calcareous conglomerate, scarcely weathered and usually steeply inclined. Initial soil formation in fissures and crests. Small patches of colluviated mineral material or organic matter in flat parts and hollows.

RO2: Rock Outcrop of limestone, dolomite, seldom calcareous sandstone or siltstone or calcareous conglomerate, carstic, with accumulation of reddish soil material and/or organic matter in fissures, crests, and hollows. Sometimes soil material has been recalcified during colluviation. Very few patches of Rhodo-Chromic Cambi- or Luvisols in situ.

RO3: Rock Outcrop on the high coast under temporary influence of salt water including Salic Fluvisols (FLs) on beaches where marine material is deposited.

\section{Rendzic Soils}

RENDZIC LEPTOSOLS: Shallow and usually stony soils with a mollic A horizon upon calcareous bedrock

LPk-CMk1 ${ }^{3}$ : Rendzic Leptosols (LPk) associated with Rendzic Cambisols (CMk ${ }^{4}$.

\footnotetext{
${ }^{3}$ Leptosols defined as shallow soils have to be presented if possible together with the symbol of the associated soil according FAO (1988).

4 Definition additional to FAO (1988) see chapter IV.3.
} 
Soils with a profound rudic and mollic A and sometimes a humic and rhodic B horizon on talus debris of gravel, stones and boulders. Typical for some footregions of cuestas and for the border middle/late Jurassic (J2-J3) on Arrábida's northern slope. Includes soils consisting mainly of accumulated organic matter with a rudic and mollic A horizon on steeply inclined layers of weathered calcareous bedrock. The weathered bedding joint between the layers and the crests of the layer's faces on the hogbacks are filled with organic (and mineral) material. This is typical for the small cuesta between J3 and J4-5 at the foot of Arrabida's northern slope and Rocha do CARDOSO.

LPk-CMk21: Rendzic Leptosols associated with Rendzic Cambisols. A mollic A horizon transfers abruptly to a calcareous B $(15 \mathrm{~cm})$ or to the weakly weathered bedrock of (impure) limestone, sometimes marl. This unit occurs on the Oligocene cuesta in the northern part of the parque.

RENDZIC CAMBISOLS: Calcareous Cambisols having a mollic A horizon or a mollic non-calcareous A horizon $30 \mathrm{~cm}$ topping calcareous material.

CMk1: Rendzic Cambisols (CMk) associated with Rendzic Leptosols (LPk) and few Calcaric Cambisols (CMc). Soils with a thick dark brown mollic A horizon often partly colluvial. The B horizon can often be divided into a highly calcareous colluviated B and a lower at least partly decalcified in situ $\mathrm{Bw}$, both of light brownish or yellowish colours. Mostly on calcareous siltstone, sandstone or conglomerate (Casa do Maneiras, northern foot of Formosinho), sometimes on colluvial recalcified residual loam under pine trees (Terras do Risco).

\section{Calcaric Soils}

CALCARIC LEPTOSOLS: Leptosols which are calcareous throughout the whole profile with an ochric A horizon. Includes calcareous soils with Ap/C profile and an Ap of $<20 \mathrm{~cm}$.

LPc-CMc1: Calcaric Leptosols (LPc) associated with Calcaric Cambisols (CMc). Intensively eroded soils with weak initial soil formation on unconsolidated impure limestone, marl, calcareous siltstone or sandstone or fine calcareous debris. A thin ochric A horizon (sometimes missing) tops an in situ Bw horizon or, more common, a B horizon from colluvial material. The B turns gradually into the intensively weathered $\mathrm{C}$. This unit is to be found on the steep coastal slope of Arrábida in the Miocene and south of Alto da Madalena.

CAMBISOLS: As the effect of decalcification usually overcomes the effects of the sedimentation of fresh material, Cambisols include soils derived from colluvial deposits showing cambic features.

CMc1: Calcaric Cambisols sometimes rhodic, including few Rhodo-Chromic Cambisols (CMc rhod). Developed on colluvium or debris of impure limestone, having a weak ochric A upon the $\mathrm{B}$ horizon covering a decalcified $\mathrm{Bw}$ or directly the intensively weathered calcareous bedrock. Yellow, yellowish brown or grey; red or reddish brown where $C M x$ material has been added. Common in steeper slope parts on impure limestone especially where soils are cultivated.

CMc2: Rhodo-Calcaric Cambisol, if shallow Rhodo-Calcaric Leptosol on parent material of red colours (calcareous conglomerates) sometimes dislocated (Vale da Rasca, Terras do Risco), easily rubifying calcareous sandstone or siltstone (C. do Maneiras, Moitelas), or from CMc/CMx rhod material mixed during colluviation (foot of S.d.S.Luís). 
Typical for areas with limestones from coastal sediments of the late Jurassic (J4-5). An ochric A, if ploughed an Ap horizon, lies upon one or several B horizons of reddish hue. Seldom remains it of an in situ weathered and decalcified or already recalcified Bw/Bwk can be found below. The $\mathrm{C}$ is usually intensively weathered.

CMc3: Calcaric Cambisols on marls and unconsolidated impure limestone, Calcaric Leptosols on consolidated impure limestone, if used for deeply ploughed vineyards (Calcaro-Aric Anthrosol ATac). There is an abrupt transition from a light yellowish brown or grey Ap horizon into the weathered C. These soils dominate the less inclined cultivated slopes of the Miocene south of Azeitão.

CMc4: Calcaric Cambisols associated with Rhodo-Chromic Cambisols (CMx rhod), sometimes Eutric Cambisols (CMe). Interlocking of mostly colluviated soil material on debris or bedrock of varying contents of $\mathrm{CaCO}_{3}$ (limestone, marl). A weakly developed ochric A tops a B or Bw horizon which is followed by a more or less abrupt transition into the intensively weathered C. These soils are located north of Rocha do Cardoso on the late J4-5 and are likely to be found at the J4-5 parts of Serra de São Luís.

CMc5: Rhodo-Calcaric associated with Rhodo-Chromic Cambisols in layers of reddish soil material colluviated from short distances on bedrock of varying contents of $\mathrm{CaCO}_{3}$ (conglomerates, calcareous sand- or siltstone). Few Rendzic Cambisols where organic matter has been accumulated under undisturbed dense vegetation. Often a decalcified Bw horizon is to be found in the subsoil, on the steep southern slope of Alto da Madalena under forest.

CALCARO-ARIC ANTHROSOLS: Calcaric Cambisol whose horizons have been disturbed by deep ploughing.

ATac1: (ATac) associated with Rendzic Cambisols where undisturbed and where organic matter is accumulated under dense vegetation. Soils of more or less red hue where Calcaric or Calcaro-Eutric Cambisols $(\mathrm{CMec})$ on marls have been disturbed by terracing, deep ploughing or intensive processes of erosion and accumulation within short distances due to human influence (clearing, pasture). They have a mighty Ap on a partly decalcified $\mathrm{Bw}$ which turns to a thin Bwk or Ck to the weathered C.

ATac2: Calcaro-Aric Anthrosols (ATac) associated with Gleyic Cambisols where Gleyic and Calcaric Cambisols have been deeply ploughed for vineyards. An Ap horizon of $80 \mathrm{~cm}$ and more is followed by the rest of an undisturbed $\mathrm{Bg}$ or directly by the $\mathrm{Cg}$ horizon. These soils are usually calcareous throughout the whole profile and of light yellowish and greyish colours. They are common south of Quinta do Anjo.

CALCARIC CAMBISOLS FROM ALLUVIAL DEPOSITS ${ }^{6}$

CMcf1: Calcaric Cambisols developed on alluvial deposits, sometimes interlocked with colluvial deposits. The ochric A already decalcified for some millimeters turns into several B horizons of yellowish colour. Beside steep slopes with rhodic soils, where talus debris has been added, rhodic and rudic phases occur. Typical unit of the small valleys at the northern foots of S. Luís, Arrábida and Risco.

CMcf2: Rhodo-Calcaric Cambisols, seldom not rhodic, or calcareous only in the lower

5 For this survey calcareous soils with an Ap/C profile and an Ap >20 cm are defined as Calcaric Cambisol, such with an Ap $20 \mathrm{~cm}$ as Calcaric Leptosol.

6 Unit of the Soil Map of the European Communities (EC 1985). 
part, from alluvial deposits. An ochric A horizon covers several layers of red B material. In the lower part of the profile often skeletal. Typical soil of the bigger valleys whose catchment bassin consists of limestone (Picheleiros creek and the valley of Alpertuche).

\section{CALCARO-VERTIC CAMBISOLS: CALCARIC CAMBISOLS SHOWING VERTIC PROPERTIES DUE TO A HIGH CONTENT OF MONTMORILLONITE OR SIMILAR CLAY MINERALS \\ CMvc1: Calcaro-Vertic Cambisols (CMvc) associated with Calcaric Cambisols, sometimes rhodic, and Eutric or Calcaric Vertisols (VRe). Calcaric Cambisols on colluvium with a high amount of clay showing vertic features or covering Eutric or Calcaric Vertisols of greyish hue. Few somewhat decalcified Vertisols from colluviated material, some having stagnic characteristics. Profiles show a ploughed or ochric A horizon on top of different B layers. Located at the foot of the steep southern slope of the Oligocene cuesta.}

\section{Eutric Soils}

CALCARO-EUTRIC CAMBISOLS

CMec2: Calcaro-Eutric Cambisols ( $\mathrm{CMec})$, Eutric Cambisols $(\mathrm{CMe})$ and Calcaric Cambisols (CMc) sometimes with stagnic features from (decalcified) debris of marl or weak calcareous sandstone or siltstone. The B under an ochric or ploughed A consists of at least two layers, the lower containing free carbonates. Colours are reddish or greyish brown. These soils are found in regions where the lithology in the late Jurassic (J4-5) changes from marine to terrestrian (Moitelas, São Caetano, Picheleiros).

\section{EUTRIC CAMBISOLS}

CMe1: Eutric Cambisols associated with Calcaric Cambisols, Calcaro-Eutric Cambisols, many of them rhodic, and Rhodo-Chromic Cambisols. They derived from intensly eroded or colluviated former Rhodo-Chromic Cambisols or Luvisols on marl or debris in the lower Jurassic of Arrábida's south slope. An ochric or sometimes mollic A horizon is followed by several reddish brown B horizons, seldom directly by a Bw. The B horizons are distinguished from a lower $\mathrm{Bw}$ or $\mathrm{C}$ by a $\mathrm{Bwk}$ or $\mathrm{Ck}$ enriched with soft powdery lime. In steeper parts transition to $\mathrm{CMc} 2$.

\section{ARIC ANTHROSOLS}

ATa1: Aric Anthrosols (ATa) associated with Eutric or Rhodo-Chromic Cambisols from which they derived by deep ploughing or, frequently, by some terracing or intensive processes of erosion and accumulation within short distances due to human influence (clearing, pasture). Medium textured soils with an ochric A upon a thick yellowish or reddish brown Ap horizon which turns gradually into a $\mathrm{B}(\mathrm{w})$. Typical for the corktree woods on sandstones and conglomerates with low $\mathrm{CaCO}_{3}$ contents in the late Jurassic (J4-5) in Picheleiros at the northern foothill of Formosinho.

\section{RHODO-CHROMIC CAMBISOLS}

CMx1: Rhodo-Chromic Cambisols (CMx rhod) associated with Rendzic Leptosols (LPk rhod) often rudic and Rock Outcrop (RO), seldom Rendzic Cambisols (CMk) and

\footnotetext{
7 Calcaric Vertisols in the FAO (1988) are presented as Eutric Vertisols.
} 
Rhodo-Chromic Luvisols (LVx rhod). On the flattened summits of the ridges of Arrábida and S.Luís, protected from erosion in crests and hollows, very few Rhodo-Chromic Luvisols are to be found. There are scarce remains of the original red mediterranean soil on limestone, now determined by clay migration, the "terra rossa" of KUBIENA (1953) and the "Solos Mediterrâneos Vermelhos de Materiais Calcários" (CARDOSO, 1965). What remains today are Rhodo-Chromic Cambisols consisting mainly of the colluviated silty topsoil of the LVx, and shallow Rendzic soils where organic matter was accumulated. All these soils are commonly rudic and situated between outcrops of hard rock (limestone, dolomite). The topsoil of the CMx is a mollic, umbric or ochric A followed by a red B which turns abruptly into a Bw or $\mathrm{C}$. The LVx are more or less eroded, an ochric or umbric A covers a red $\mathrm{EB}$ or directly the Bt horizon.

At the less inclined Serra do Risco the situation is similar, though here yellowish colours dominate ("terra fusca/Braunlehm" of KUBIENA, 1953). Probably the lower relief intensity and the less inclined geological layers resulted in a higher soil humidity and thus in the formation of Goethite instead of Hematite. In the surveyed area this material was found colluviated and partly recalcified at the Terras do Risco.

CMx2: Chromic Cambisols with few Chromic Luvisols, both usually rhodic. They are fine textured when made from decalcified or non-calcareous (red) conglomerates, or coarse to medium textured when made from sandy slope debris. Often the Chromic Cambisol overlies an eroded Luvisol. Typical horizon sequences are an ochric A followed by one or two $\mathrm{B}$, a $\mathrm{Bw}$ or $\mathrm{EB}$ horizon and a Bt, sometimes Btg, in the subsoil. These soils are common on both sides of Picheleiros creek west of Vale da Rasca.

\section{EUTRIC GLEYSOLS}

GLe1: Eutric Gleysols associated with Gleyic Cambisols. On slopes and in the valleys where the groundwater table is close to the surface. Stagnic and reductive features occur only in flattened positions, otherwise they are missing. A ploughed or ochric A horizon is followed directly by a gleyic B, greyish mottled or reddish with concretions. Typical for the level western part (Ribeira de Terras do Risco), in the east only in small areas with springs (Serra de Louro).

\section{Coarse Textured Eutric Soils}

\section{HAPLIC LUVISOLS}

LVh1: Haplic Luvisols associated with Luvic Arenosols and Stagno-Gleyic Luvisols. The latter occur on flattened summit positions and are sometimes eroded to a Litho-Eutric Leptosol. On the slopes these soils are eroded and at the footslopes there the colluvia lie, often with gleyic or stagnic influence, forming Gleyic and Eutric Cambisols. These soils are classified as Eutro-Gleyic Cambisols (CMeg1). The Haplic Luvisols derive mainly from calcareous sandstone. They are of coarse to medium texture with varying light colours and comparatively low clay contents in the argillic horizon. Horizon sequences of undisturbed profiles are an ochric A, sometimes a relict Ap, followed by an E as the eluvial and a Bt as the illuvial horizon, and a Bw before the weathered and more or less decalcified C. These soils are typical for the region between the road from C.d.Serra to Pedreiras and Ribeira de Terras do Risco/Parral. Some of the Haplic Luvisols, especially where eroded, still have a base saturation product of almost $100 \%$ or are even calcareous, but most of them show 
dystric features which are hidden by the effect of recent aeolic deposits. This unit together with $\mathrm{CMeg} 1$ therefore is an intermediate stage between originally eutric soils grouped under 4.5 and the following formerly dystric soils (4.6.3 f).

\section{EUTRO-GLEYIC CAMBISOLS}

CMeg1: Gleyic Cambisols associated with Calcaric Cambisols. Soil unit to be found mainly in the neighbourhood of LVh1 on the slopes to Ribeira de Terras do Risco in the coastal sediments of the late Jurassic (J4-5). Eroded soils or soils from colluvium on sandstone or conglomerate with few carbonates influenced by subsurface flow. Usually an ochric A horizon is followed by a B or Bw horizon turning gradually into a Bg. A reductive $\mathrm{Br}$ does not always occur.

\section{EUTRIC CAMBISOLS}

CMe2: Eutric Cambisols and few Humic Cambisols and Aric Anthrosols. Coarse textured soils of light reddish or yellowish, sometimes greyish brown. With or without an umbric A horizon on a $\mathrm{B}(\mathrm{w})$ from colluvium or debris of sandstones and fine quartz conglomerates of the late Jurassic (J4-5). In valleys generally medium textured (sandy loam or loamy sand), of reddish hue and deeply ploughed if cultivated (ATa).

CMe3: Eutric Cambisols associated with Eutric Leptosols. Soil profiles comparable to $\mathrm{CMe} 2$ but generally in situ and less thick due to erosion and relief. In the late Jurassic and the Cretaceous near São Caetano and on the watersheds in the valleys of the Ribeiras de Alcube and Corva in the east.

CMe4: Eutric Cambisols associated with Aric Anthrosols developed from CMd by terracing on sandy conglomerates of the Cretaceous (Picheleiros). Profiles are $(\mathrm{O}) / \mathrm{Aoc} / \mathrm{B} / 2 \mathrm{Bw} / 2 \mathrm{C}$, of coarse to medium texture and from at least 60 to more than $100 \mathrm{~cm}$ thick.

CMe5: Gleyo-Eutric Cambisols (CMeg) associated with Luvic Arenosols (ARl), both sometimes with stagnic features. Coarsely textured soils with light grey, brownish or yellowish grey hue from sands, sandstones or sandy conglomerates (Pliocene, Cretaceous, J4-5). For the special use of the area at Portela da Sardinha, where this unit mainly occurs as horse pasture, the $\mathrm{Ap}$ is ploughed. It follows a $\mathrm{B}(\mathrm{w}) \mathrm{g}$ horizon or an $\mathrm{E}$ with a $\mathrm{Bt}(\mathrm{g})$ and sometimes $\mathrm{Bw}$ before the $\mathrm{C}(\mathrm{g})$. The low AWCr is partly enlarged by interflow. The soils are about $50-100 \mathrm{~cm}$ thick.

CMe6: Eutric Cambisols on slopes associated with Cambic or Gleyic Arenosols from alluvial deposits (ARbf, ARgf) in the valleys and Stagno-Arenic Luvisols on sandstone or conglomerate, covered by a thin layer of sand in flattened summit positions. All showing some stagnic or gleyic features. The topsoils are coarsely textured, the subsoils coarse or medium, sometimes finer, depending on the ratio between sand and conglomerates in the parent material. Colours are grey, yellowish grey and greyish brown. An ochric A is followed by a B or Bw which tops a mottled Bg. The $\mathrm{C}$ is of intensive red or yellow hue, due to high contents of iron. This unit is restricted to the transition from Pliocene/Pleistocene sands to the Cretaceous conglomerates near Alto das Vinhas.

ARIC ARENOSOLS: Arenosols from sandy colluvial or aeolic deposits containing organic matter in the whole profile and showing features similar to deep ploughing.

ARa1: Aric Arenosol (ARa), often with few gleyic/stagnic properties. These are 
coarsely textured soils of dislocated sand containing organic matter throughout the whole profile. The features, although resulting from aeolic transport or colluviation, because of a long term agricultural use, are similar to the ones of deep ploughing, so the name Aric Arenosol has been chosen. The top horizon is a thick ochric or humic A, if not ploughed. It is followed by a buried A and a Bw or Bwg. At Parral there is a buried Ap horizon at about $50-70 \mathrm{~cm}$ below surface, the available water amount is enlarged by interflow. Aric Arenosols are situated at a belt along the northern border of the Parque where the Pliocene starts and in the heathlands west of Parral.

\section{CAMBIC ARENOSOLS}

ARb1: Cambic Arenosols (ARb), some showing stagnic features, associated with Eutric Cambisols. This unit is the counterpart of the latter in regions where little or no agriculture took place. Coarsely textured soils of low fertility derived from sand, weathered sandstone or sandy conglomerate, showing cambic and/or stagnic, seldom luvic or podzolic features. There is a transition from a usually greyish brown ochric A into a yellowish or reddish brown $\mathrm{B}(\mathrm{w})$ and then into a $\mathrm{Bw}, \mathrm{Bg}$ or $\mathrm{BC}$. The unit occurs only in the west near Ribeira de Terras do Risco and close to Alto das Vinhas.

\section{LUVIC ARENOSOLS}

AR11: Luvic Arenosols associated with Gleyic Arenosols (ARg) alternating and interlocked with and partly overlying Eutric Vertisols (VRe) (southern foot slope at Cuco). Many of these soils consist of a layer of Pliocene/Pleistocene sands, sometimes already mixed with clay by colluviation, and show an abrupt textural change from the sandy to the loamy-clayey layer. The gleyic properties resulting from subsurface flow are often rather weakly expressed. The abrupt textural change is mainly geogen; clay enrichment by illuviation is negligible. Horizon sequences are $\mathrm{Ap} / \mathrm{Bwg}$ for the $\mathrm{ARg}$ and $\mathrm{Ap} / \mathrm{B} / 2 \mathrm{Bt}(2 \mathrm{Bw})$ for the combined profiles. The Arenosols themselves are free of carbonates but the unit includes a few calcareous Eutric Vertisols.

\section{GLEYIC ARENOSOLS}

ARg1: Gleyic and Stagno-Gleyic Arenosols (ARg,ARgj) associated with Gleyic Cambisols $(\mathrm{CMg})$. Coarse textured Gleysols and Stagnic Gleysols with ground and/or surface water influence up to the topsoil. The ochric A is followed by a Bg or Cr. A singular unit at some places along the borders of Ribeira de Terras do Risco.

\section{Dystric Soils}

\section{HAPLIC PODZOLS}

PZ1: Ferric and Haplic Podzols (PZf, PZh) on Pliocene/Pleistocene sands. The organic layer is followed by an umbric A which turns into a bleached $\mathrm{E}$. The Bs is thin and not indurated and is followed by a cambic Bw. BSP and CEC are very low, AWCr is low. This unit includes a small area of Haplic Luvisols on loamy silt of unknown origin covering eroded Podzols near Parral. Podzols are situated e.g. near Parral and north of Vinhas in the western part of the Parque and in a small area at Arneiros near Cuco. 


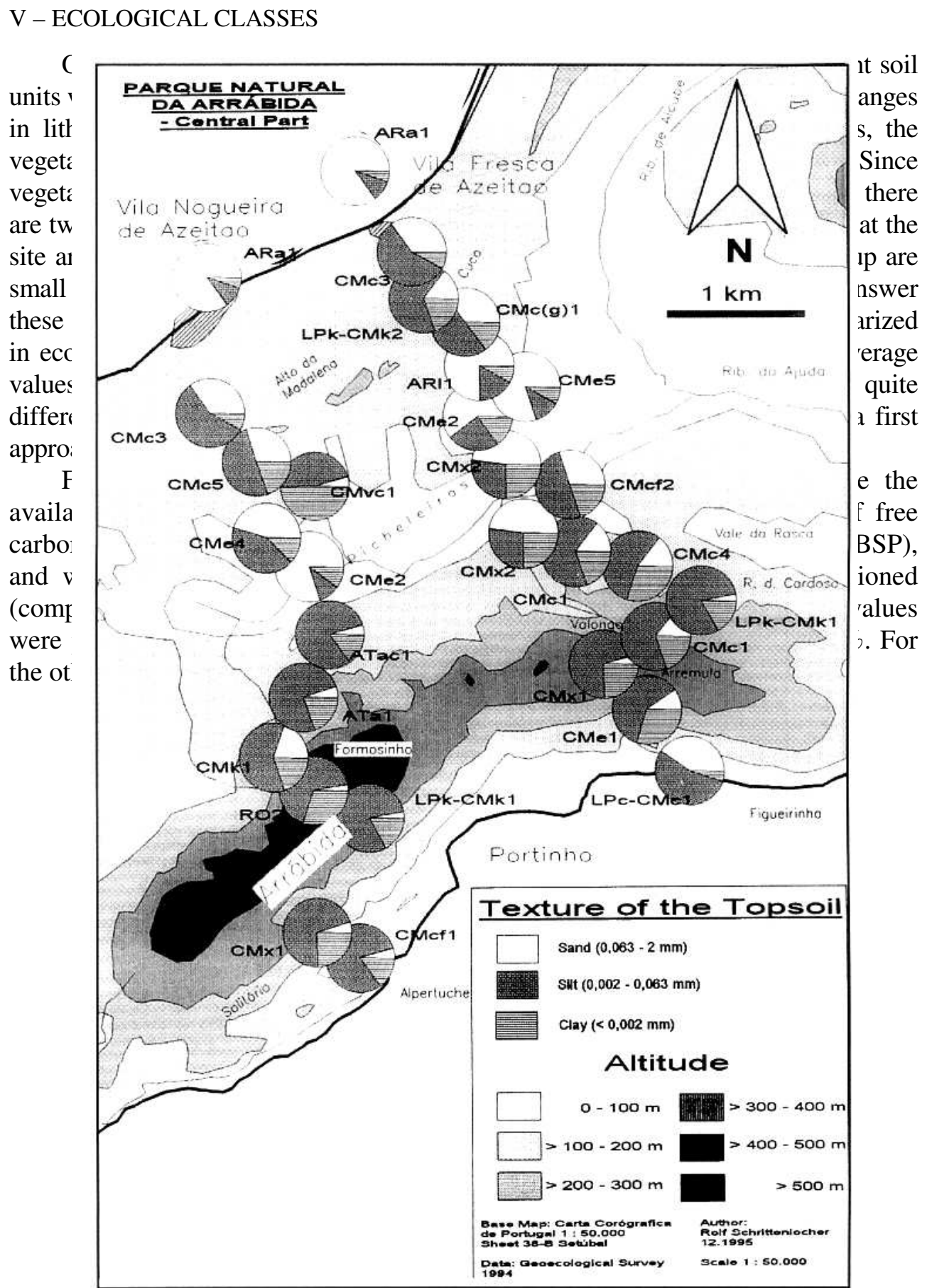

Fig. 3 - Catenae 1 and 2: Soil Texture

Fig. 3 - Transectos 1 e 2: Textura dos solos 


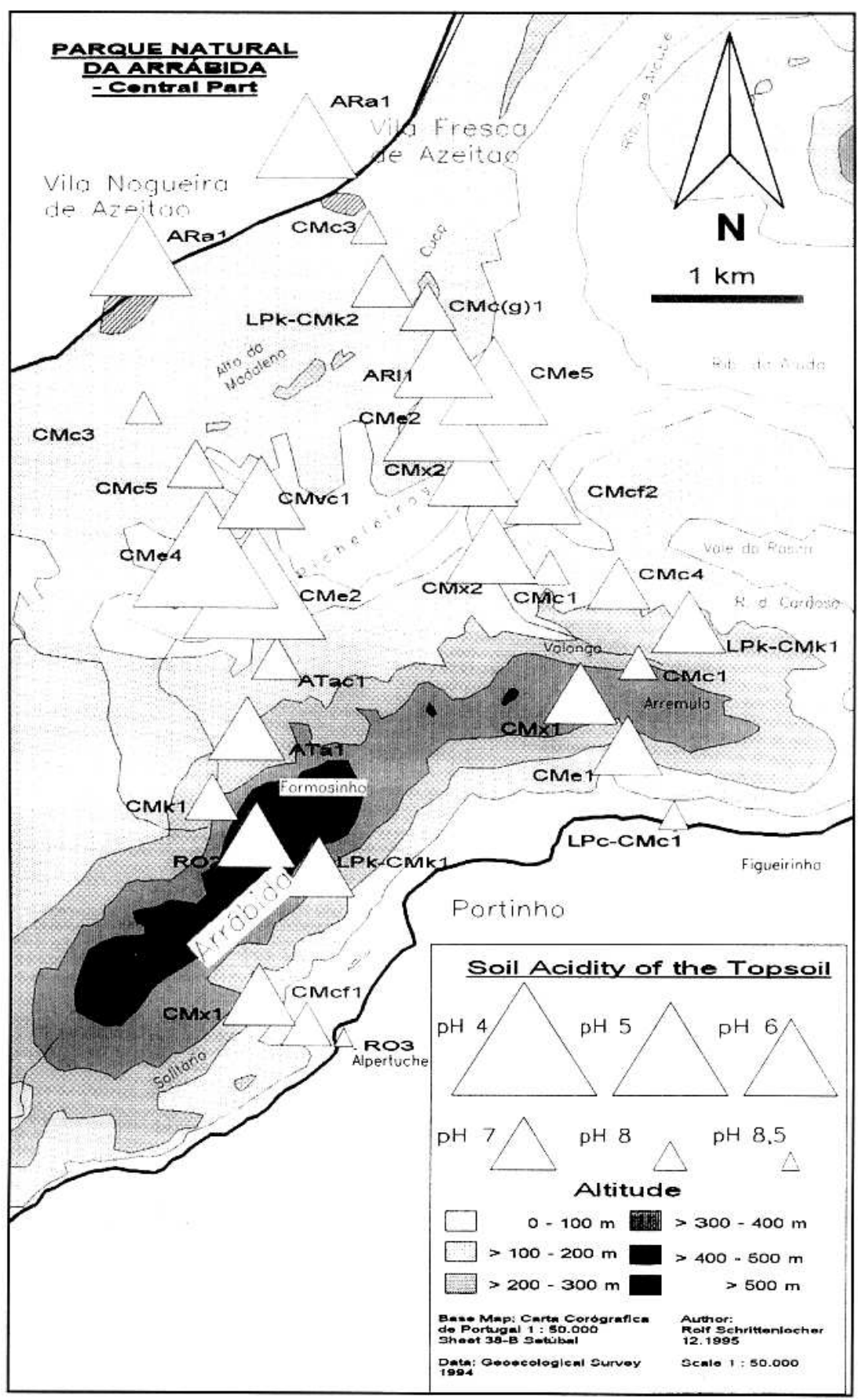




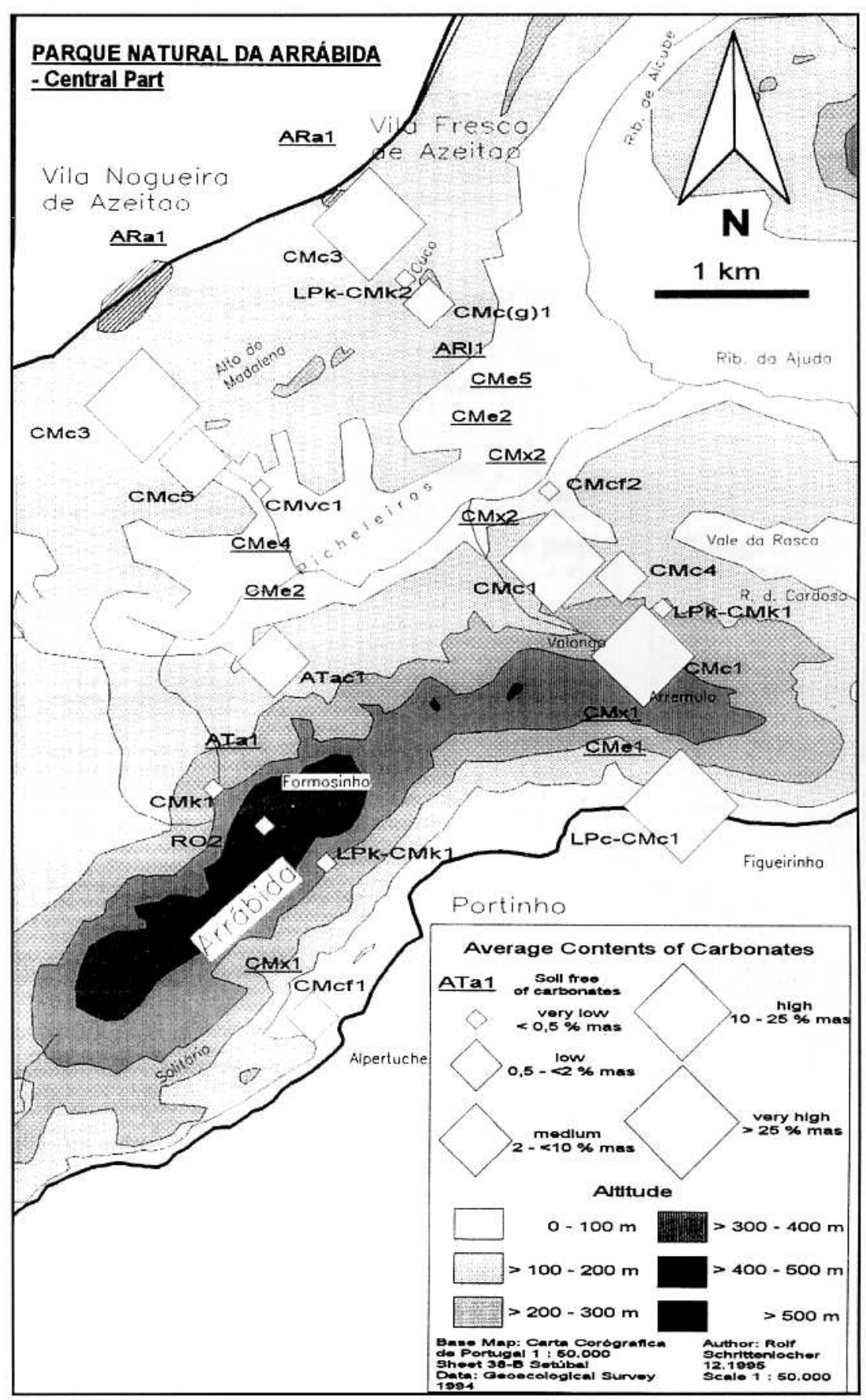

Fig. 5 - Catenae 1 and 2: Free Carbonates

Fig. 5 - Transectos 1 e 2: Percentagem de carbonatos livres 


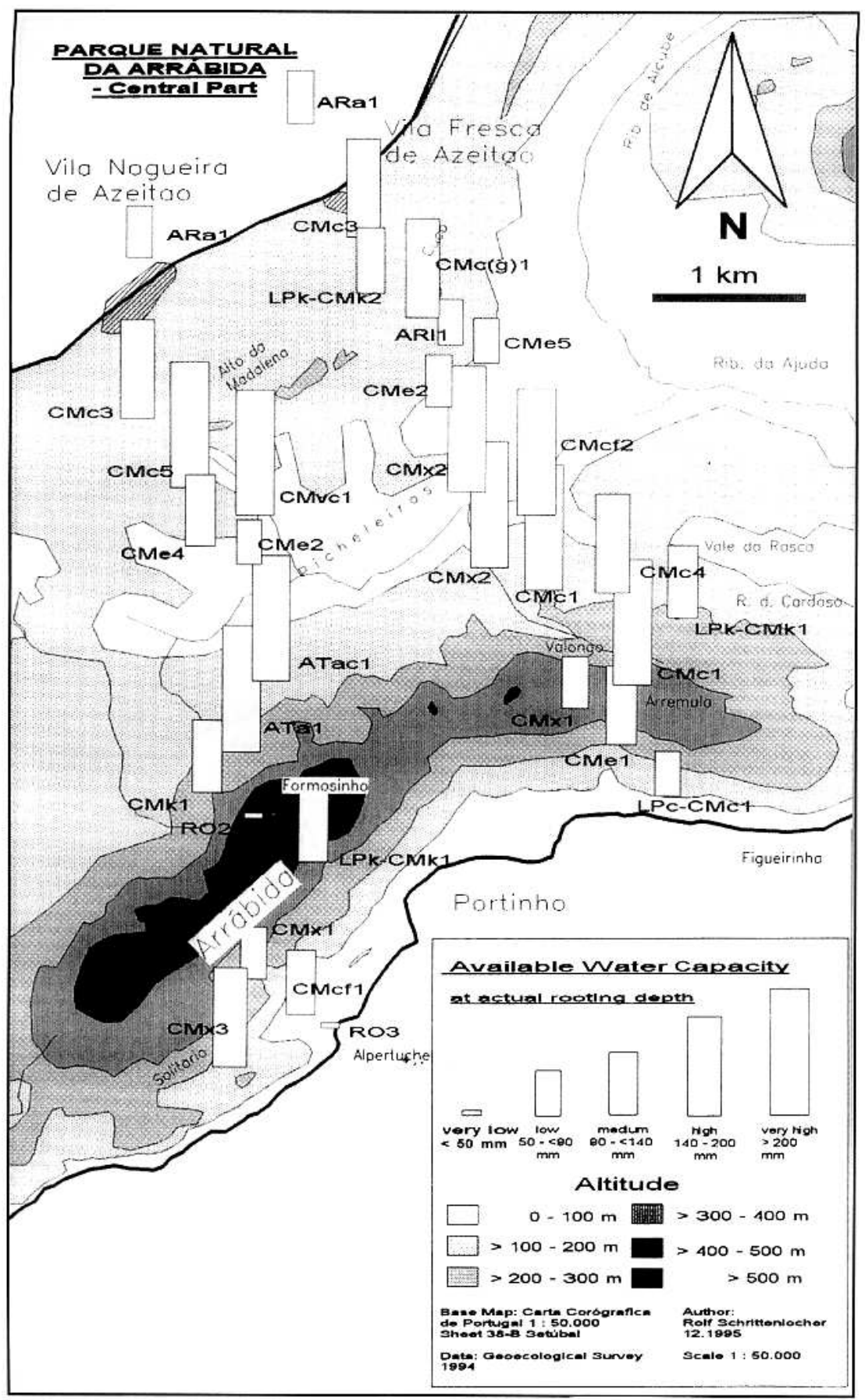

Fig. 6 - Catenae 1 and 2: Available Water Capacity at Actual Rooting Depth Fig. 6 - Transectos 1 e 2: Capacidade de água utilizável no espaço das raízes 


\section{Fertile Soils}

\subsection{Fertile Soils with a Very Low or a Low Available Water Capacity}

Rock Outcrop and Initial Soils (Units RO1, RO3, LPc-CMc1). This class is to be found at the steep cuestas especially on the coastal slope of Arrábida on Jurassic limestone or dolomite as well as on impure limestone of the Tertiary cuesta in the hinterland. Soils, if existing at all, are usually shallow, the AWCr is very low or low, and there is an abundance of free carbonates. The $\mathrm{pH}$ is $>8$. Where loose material is accumulated it is generally of medium texture. The class is restricted to steep slopes and escarpments.

Rock Outcrop and Rendzic Soils (Unit RO2). A class situated on summit positions and slope shoulders of the main ridge of Arrábida. Between outcrops of limestone or dolomite there are shallow soils with a low or very low AWCr. The soil matrix is free of carbonates, but often contains skeletal limestone. The average $\mathrm{pH}$ is about 6.2 with a range from 5.9 to 6.3 . The texture is medium and the relief is rather flat.

\subsection{Fertile Soils with a Medium Available Water Capacity}

Rudi-Rendzic Soils (Unit LPk-CMk1). A class occuring at the small ridge of almost vertical layers of limestone at the transition from Oxfordian to Kimmeridgian (J3/J4-5) north of Arrábida's main chain, at the border of middle/late Jurassic (J2/J3) on talus debris, and at the footregions of some cuestas e.g. São João do Deserto. Soils are deep with an organic layer of $5-50 \mathrm{~cm}$ and usually a mineral layer with approx. $50 \%$ organic matter in the fine earth fraction, both horizons containing up to $90 \%$ gravel, stones, and boulders. AWCr can only be estimated and varies widely from low to medium. In many cases roots of phanerophytes are able to penetrate into the weathered bedding joints and get some surplus water. The average $\mathrm{pH}$ is about 6.6 , varying from 5.8 to 7.6 with one exception at 8.6. The texture is medium and the relief is variable.

Rendzic Soils (Units LPk-CMk2, Cmk1). The class is characterized by a $\mathrm{pH}$ between 6.3 and 8.1 with an average at 7.2. Some but not all soils contain free carbonates due to colluviation, most of them have some calcareous skeletal material. They are generally medium textured soils in a rolling or steep relief. The AWCr is medium or low to medium. Soils of this class are to be found on the northern slope of the Tertiary cuesta near Cuco on limestone, at some small spots on top of little cuestas in the late Jurassic (J4-5) north of Serra de São Luís and on Formosinho's northern slope on marl and calcareous sandstone.

Non-Calcareous Soils of Medium or Fine Texture (Units CMe1, Cmx1). This class is restricted to the main chains of S.Luís, Arrábida, Risco, and their northern foothills. AWCr varies depending on the thickness of the soils, the average value is between low and medium. The units include some calcareous soils, but in general 
there are no free carbonates and the $\mathrm{pH}$ lies between 5.8 and 7.5 with an average of 6.6. The texture is usually medium, but fine or coarse texture occurs as well. The class can be found on gently inclined and on steep slopes.

Table I - Fertile Soils with a Very Low, a Low or a Medium Available

Water Capacity at Actual Rooting Depth (AWCr)

Quadro I - Solos férteis com uma capacidade de água utilizável no espaço das raízes muito pequena ou média

\begin{tabular}{|c|c|c|c|c|c|c|c|c|c|}
\hline Unit & $\begin{array}{l}\text { Slope/ } \\
\text { Texture } \\
\text { Class }^{1}\end{array}$ & $\begin{array}{l}\text { Texture }^{2} \\
\text { (Topsoil) }\end{array}$ & $\mathrm{AWCr}^{3}$ & $\begin{array}{l}\mathrm{pH}^{4} \\
\text { (av.) }\end{array}$ & $\begin{array}{l}\mathrm{pH}^{4} \\
\text { var. }\end{array}$ & $\mathrm{CaCO}_{3}{ }^{5}$ & $\mathrm{CEC}^{6}$ & $\begin{array}{c}\mathrm{BSP}^{6} \\
\%\end{array}$ & $\begin{array}{l}\text { Stoni- } \\
\text {-ness }\end{array}$ \\
\hline RO1 & $\mathrm{c}$ & - & very low & 8 & & $* * *$ & $\begin{array}{c}\text { medium or } \\
\text { higher }\end{array}$ & 100 & $* * *$ \\
\hline RO3 & $a-c$ & - & very low & 8.5 & $8.1-9.2$ & $* * *$ & $\begin{array}{c}\text { medium or } \\
\text { higher }\end{array}$ & 100 & $\begin{array}{c}* * \\
(* * *)\end{array}$ \\
\hline $\begin{array}{l}\text { LPc- } \\
\text { CMc1 }\end{array}$ & $2 b-c$ & Us,U13 & low & 8.1 & 7.9-8.2 & $* * *$ & $\begin{array}{c}\text { medium or } \\
\text { higher }\end{array}$ & 100 & $(*)$ \\
\hline $\mathrm{RO} 2$ & $2 \mathrm{ab}$ & U12 & very low & 6.5 & $6-8.6$ & $(*)$ & $\begin{array}{c}\text { medium or } \\
\text { higher }\end{array}$ & 100 & $* *$ \\
\hline $\begin{array}{c}\text { LPk- } \\
\text { CMk1 }\end{array}$ & $2(b) c$ & U13 & medium & 6.6 & 5.8-6.6 & $(*)$ & $\begin{array}{c}\text { medium or } \\
\text { higher }\end{array}$ & 100 & $* * *$ \\
\hline $\begin{array}{c}\text { LPk- } \\
\text { CMk2 }\end{array}$ & $2 a-c$ & $\mathrm{Ul3}, \mathrm{Lu}$ & $\begin{array}{c}\text { medium- } \\
\text {-low }\end{array}$ & 7 & $6.5-7.4$ & $(*)$ & $\begin{array}{c}\text { medium or } \\
\text { higher }\end{array}$ & 100 & $*$ \\
\hline CMk1 & $2 a-b,(1 c)$ & $\mathrm{Ul3}, \mathrm{Lu}$ & medium & 7.3 & $6.3-8.1$ & (*) & $\begin{array}{c}\text { medium or } \\
\text { higher }\end{array}$ & 100 & $(* *)$ \\
\hline CMe1 & $2 b c$ & U13 & $\begin{array}{l}\text { Medium- } \\
\text {-high }\end{array}$ & 6.7 & & $(* *)$ & $\begin{array}{c}\text { medium or } \\
\text { higher }\end{array}$ & 100 & $*$ \\
\hline CMx1 & \begin{tabular}{|c|}
$2 a b, 2-3 b$ \\
$2 c, 1-2 b$
\end{tabular} & $\mathrm{Lu}, \mathrm{U} 14$ & $\begin{array}{c}\text { Medium- } \\
\text {-low }\end{array}$ & 6.6 & $5.8-7.5$ & - & $\begin{array}{c}\text { medium or } \\
\text { higher }\end{array}$ & 100 & $\begin{array}{c}* \\
(* *) \\
\end{array}$ \\
\hline CMec2 & $1 \mathrm{~b}-2 \mathrm{ab}$ & U13 & $\begin{array}{l}\text { High- } \\
\text {-medium }\end{array}$ & 6.4 & $6-7.2$ & $(* *)$ & $\begin{array}{c}\text { medium or } \\
\text { higher }\end{array}$ & 100 & - \\
\hline
\end{tabular}

1 see FAO 1988

2 see AG BondENKUNDE 1982. Dominating texture is presented first.

$3<50$ mm very low; 50 - 90 mm low; 90 - 140 mm medium; 140 - $200 \mathrm{~mm}$ high, > $200 \mathrm{~mm}$ - very high (Ag BONDENKUNDE, 1982).

${ }^{4} \mathrm{pH}(\mathrm{KCl})$

$5 *<2 \% ; * * 2-25 \%$; *** $>25 \%$. Values occuring occasionally in brackets

6 includes soluable salts.

Non-Calcareous Soils of Medium Texture (Unit Cmec2). A class similar to the one above, but with generally medium, sometimes coarsely, textured soils of medium or medium to high AWCr. The $\mathrm{pH}$ has an average of 6.2 and varies from 
5.8 to 7.2. The subsoil is calcareous, bedrock is a calcareous sandstone or conglomerate usually of the late Jurassic (J4-5).

\subsection{Fertile Soils with a High or a Very High Available Water Capacity}

Highly Calcareous Soils with a Very High AWCr of Medium Texture (Units $\mathrm{CMc} 1, \mathrm{CMc} 2, \mathrm{Cmc} 3)$. This class is significant for extremely eroded soils on loose calcareous material or calcareous soils from not yet decarbonated material of colluvial origin. The soils have an abundance of free carbonates and the average $\mathrm{pH}$ is 7.8. They are generally medium, sometimes medium to coarse textured, and occur in areas with a soft relief. The AWCr is very high or high, but plants there might be affected by physiological dryness because of the lack of potassium and a surplus of calcium in the soil water solution. In addition, there is an increased loss of water by evaporation because of capillary ascent. There is a widespread distribution of this class on the late Jurassic (J3 and J4-5) and the Miocene beside the main ridges.

Highly Calcareous Soils with a High AWCr (Units ATac1, ATac2, CMcf1, $\mathrm{CMc} 4, \mathrm{Cmc5}$ ). Some of these units contain soils with a certain, rarely a total loss of free carbonates. The $\mathrm{pH}$ ranges from 6.5 to 8.1 with an average at 7.3. $\mathrm{CaCO}_{3}$ contents are medium, BSP is $100 \%$. The AWCr is very high or high. The soils of this class are medium, sometimes fine textured, and restricted to rolling or steep relief, with the exception of the soils from fluvic deposits. They occur in the late Jurassic (J4-5) and the Paleogene on generally translocated parent material from limestone, dolomite or marl and on alluvium of these materials.

Partly Calcareous Soils with a Very High AWCr of Heavy Texture (Unit Cmvc1). This specific unit cannot be grouped with others because of the special features of its soils. It is characterised by Cambisols with vertic properties and Vertisols of medium or fine texture, some of them containing free carbonates. The $\mathrm{pH}$ differs from 5.3 to 7.2 with an average of 6.2. Clay activity is high and so is the AWCr. This class is not only found in depressions but sometimes on steep slopes as well. It is restricted to the Paleogene where the clayey parent material was deposited and later during colluviation partly mixed with silt.

Non-Calcareous Soils with a Medium or a High AWCr (Units CMx2, ATa1, Cmcf2). In this class soils of the late Jurassic (J4-5) and alluvial soils are assembled. They are generally free of carbonates in the topsoil but have a BSP of almost $100 \%$ and a $\mathrm{pH}$ of an average of 6.3 (6.0-7.4). The subsoil or the parent material is sometimes calcareous (conglomerates, sandstones). Often the soil material was translocated or the soils were eroded. Soils of this class are usually more than $100 \mathrm{~cm}$ thick, the AWCr is medium or high, sometimes very high. They are situated on slopes of varying inclination with the exception of the alluvial soils in the valleys. Their texture varies from coarse to medium, seldom fine.

Table II: Fertile Soils with a High or a Very High Available Water 
Capacity at Actual Rooting Depth

Quadro II: Solos férteis com grande ou muito grande capacidade de água utilizável no espaço das raízes

\begin{tabular}{|c|c|c|c|c|c|c|c|c|c|}
\hline Unit & $\begin{array}{c}\text { Slope/ } \\
\text { Texture } \\
\text { Class }^{1}\end{array}$ & $\begin{array}{l}\text { Texture }^{2} \\
\text { (Topsoil) }\end{array}$ & $\mathrm{AWCr}^{3}$ & $\begin{array}{l}\mathrm{pH}^{4} \\
\text { (av.) }\end{array}$ & $\begin{array}{l}\mathrm{pH}^{4} \\
\text { var. }\end{array}$ & $\begin{array}{c}\mathrm{CaCO}_{3} \\
5\end{array}$ & $\mathrm{CEC}^{6}$ & $\begin{array}{c}\mathrm{BSP}^{6} \\
\%\end{array}$ & $\begin{array}{l}\text { Stoni- } \\
\text {-ness } 5\end{array}$ \\
\hline CMc1 & 2(3)b-c & Ul3,Ul4,Ltu & very high & 7.8 & $7.2-8.3$ & $\begin{array}{c}* * \\
(* * *)\end{array}$ & $\begin{array}{c}\text { medium or } \\
\text { higher }\end{array}$ & 100 & $(*)$ \\
\hline $\mathrm{CMc} 2$ & $2 a-c, 1-2 b$ & U13 & very high & 7.8 & $7.2-8.1$ & $* *$ & $\begin{array}{c}\text { medium or } \\
\text { higher }\end{array}$ & 100 & $(*)$ \\
\hline $\mathrm{CMc} 3$ & $1-2 a b$ & Us,Uls,U12 & high & 7.9 & & $* * *$ & $\begin{array}{c}\text { medium or } \\
\text { higher }\end{array}$ & 100 & (*) \\
\hline CMc4 & $2-3 c$ & Ltu & high & 6.5 & & $(* * *)$ & $\begin{array}{c}\text { medium or } \\
\text { higher }\end{array}$ & 100 & (*) \\
\hline CMc5 & $2 c$ & Ls2 & very high & 7.2 & $6.8-7.5$ & $(* *)$ & $\begin{array}{c}\text { medium or } \\
\text { higher }\end{array}$ & 100 & (*) \\
\hline CMcf1 & $2 a, 2-3 a b$ & U13 & very high & 7.4 & & $\begin{array}{c}* * \\
(* * *)\end{array}$ & $\begin{array}{c}\text { medium or } \\
\text { higher }\end{array}$ & 100 & $(* *)$ \\
\hline ATac1 & $2 b c$ & U13 & very high & 7.4 & & $*(*)$ & $\begin{array}{c}\text { medium or } \\
\text { higher }\end{array}$ & 100 & $(*)$ \\
\hline ATac2 & $2 b$ & U13 & very high & 7.5 & $6.8-8.1$ & $(* * *)$ & $\begin{array}{c}\text { medium or } \\
\text { higher }\end{array}$ & 100 & - \\
\hline CMve1 & $2-3 a-c$ & Lu,Ltu & very high & 6.1 & $5.3-7.2$ & $(* *)$ & $\begin{array}{c}\text { medium or } \\
\text { higher }\end{array}$ & 100 & (*) \\
\hline CMcf2 & $2 b, 2 a$ & Ls3,U13 & very high & 6.5 & $6-7.4$ & $(*)$ & $\begin{array}{c}\text { medium or } \\
\text { higher }\end{array}$ & 100 & $(*)$ \\
\hline ATa1 & $2 b$ & $\mathrm{Ul3}, \mathrm{Lu}$ & very high & 6.5 & & - & $\begin{array}{c}\text { medium or } \\
\text { higher }\end{array}$ & 100 & $*$ \\
\hline $\mathrm{CM} 2$ & $(1-2) 3 c$ & S13-Lts & very high & 6 & 6.0-6.4 & - & $\begin{array}{c}\text { medium or } \\
\text { higher }\end{array}$ & 100 & $(*)$ \\
\hline
\end{tabular}

1 see FAO, 1988.

2 see Ag BondenKunde, 1982. Dominating texture is presented first.

$3<50 \mathrm{~mm}$ very low; 50 - $90 \mathrm{~mm}$ low; 90 - $140 \mathrm{~mm}$ medium; 140 - $200 \mathrm{~mm}$ high, $>200 \mathrm{~mm}$ very high (AG BONDENKUNDE, 1982).

${ }^{4} \mathrm{pH}(\mathrm{KCl})$

$5 *<2 \%$; ** $2-25 \% ; * * *>25 \%$. Values occuring occasionally in brackets

6 includes soluable salts.

\section{Less Fertile Soils with a Low or a Medium Available Water Capacity}

Non-Calcareous Soils with a Low AWCr of Light Texture (Units CMe2, 
CMe3, CMe4, CMe5, CMe6, ARa1, ARb1, ARl1, PZ1). In this broad class many units with different features are collected. What they have in common is that they are all coarse textured, mainly sand or sometimes sandy loam, and have a very low or low CEC. The BSP is varying between 40 and $95 \%$, the pH actually lies between 3.6 and 6.4 with an increased frequency between 4.1 and 5.6, the average being 4.9. The AWCr is low or low to medium, depending on the texture, very seldom medium. The class is situated in noncarbonatic late Jurassic (J4-5), Cretaceous, and the Pliocene/Pleistocene sands in the level to rolling western part of the Parque.

Non-Calcareous Soils with a Medium AWCr of Light Texture (Units LVh1, CMeg1, Cmec1). A class with soils from calcareous sandstone and similar bedrock, generally coarse textured and of medium AWCr. As due to erosion some calcareous soils are included, $\mathrm{pH}$ varies from 4.9 to 7.9 with an average of 6.1 and most values between 5.4 and 6.6. The soils with a lower $\mathrm{pH}$ show a decrease of the $\mathrm{pH}$ to the subsurface horizons because of calcareous aeolic deposits in the topsoil. The lower subsoil and/ or the parent material is calcareous again. The BSP is sometimes $<100 \%$ and the CEC is low or very low.

\section{Hydromorphic Soils (Units GLe1, Arg1).}

Only soil units where hydromorphic features are dominant are assembled in this class. The water saturation from flowing groundwater or interflow is close to the surface throughout much of the year, therefore watercontents are high but the rooting depth for many plants is limited. The parent material of these soils is varying, so is the texture from coarse to medium. There is no $\mathrm{CaCO}_{3}$ to be found and the $\mathrm{pH}$ varies between 5.3 and 6.4. The class occurs only in level or gently undulating areas.

\section{VI - POSSIBILITIES OF CORRELATION WITH THE PORTUGUESE SOIL MAP 38-B}

\section{The Portuguese Soil Map}

For the surveyed region a two-sheet soil map already exists. The soil map in the narrower sense Carta dos Solos de Portugal $38 B$ and a sheet for agricultural use Carta de Capacidade de Uso dos Solos 38B in the scale of 1: 50000 (SROA, 1969). Field maps in 1: 25000 are available as transparent overlay but do not give much more information.

The first sheet of the map gives information about the type of soils according to the Portuguese classification. Soils are assembled in soil units, phases are shown as overprint. The second sheet shows the agricultural "capacity", comparable to a

Table III - Less Fertile Soils with a Low or a Medium Available Water Capacity at Actual Rooting Depth (AWCr) and Hydromorphic Soils

Quadro III - Solos menos férteis com uma capacidade de água utilizável 
no espaço das raízes pequena ou média

\begin{tabular}{|c|c|c|c|c|c|c|c|c|c|}
\hline Unit & $\begin{array}{c}\text { Slope/ } \\
\text { Texture } \\
\text { Class }^{1}\end{array}$ & $\begin{array}{c}\text { Texture }^{2} \\
\text { Topsoil/ } \\
\text { Subsoil }\end{array}$ & $\mathrm{AWCr}^{3}$ & $\begin{array}{l}\mathrm{pH}^{4} \\
\text { (av.) }\end{array}$ & $\begin{array}{l}\mathrm{pH}^{4} \\
\text { var. }\end{array}$ & $\mathrm{CaCO}_{3}{ }^{5}$ & $\mathrm{CEC}^{6}$ & $\begin{array}{c}\mathrm{BSP}^{6} \\
\%\end{array}$ & $\begin{array}{l}\text { Stoni- } \\
\text {-ness }\end{array}$ \\
\hline $\mathrm{CMe} 2$ & $1 b(-2 a)$ & S,Slu,S12 & $\begin{array}{c}\text { low - } \\
\text { medium }\end{array}$ & 5.1 & $4.3-5.9$ & - & $\begin{array}{c}\text { very low - } \\
\text { low }\end{array}$ & 85 & (*) \\
\hline CMe3 & $1-2 b$ & $\mathrm{~S}, \mathrm{Su} 3, \mathrm{~S} 12$ & low & 4.2 & $3.6-4.7$ & - & \begin{tabular}{|c|} 
very low - \\
low
\end{tabular} & 85 & (*) \\
\hline $\mathrm{CMe} 4$ & $1-2 b$ & S13,U13 & medium & 4.1 & & - & $\begin{array}{c}\text { very low - } \\
\text { low }\end{array}$ & 95 & (*) \\
\hline CMe5 & $1 a, 1-2 b$ & $\mathrm{~S}, \mathrm{Ls} 2, \mathrm{~S} 13$ & low & 5.4 & $5.3-5.4$ & - & $\begin{array}{c}\text { very low - } \\
\text { low }\end{array}$ & 100 & - \\
\hline CMe6 & $1 \mathrm{ab}$ & $\begin{array}{c}\mathrm{S}, \mathrm{S} 12 \\
(/ \mathrm{U} 12, \mathrm{Lts}) \\
\end{array}$ & low & 5.5 & $5.3-5.7$ & - & very low & 70 & (*) \\
\hline ARa1 & $1 \mathrm{a}$ & $\mathrm{S}$ & $\begin{array}{c}\text { low - } \\
\text { medium }\end{array}$ & 5.6 & $5.1-6.4$ & - & very low & 80 & - \\
\hline $\mathrm{ARb} 1$ & $1 b$ & $\begin{array}{c}\mathrm{S}, \\
(\mathrm{S} 12, \mathrm{Ls} 3, \mathrm{~L} \\
\mathrm{u})\end{array}$ & $\begin{array}{c}\text { low - } \\
\text { medium }\end{array}$ & 5.5 & $4.9-6.1$ & - & $\begin{array}{c}\text { very low - } \\
\text { low }\end{array}$ & 100 & - \\
\hline ARl1 & $1-3 a$ & \begin{tabular}{|c} 
S12,(S,Su3, \\
Ls3)/Ltu
\end{tabular} & low & 5.7 & & - & $\begin{array}{c}\text { medium or } \\
\text { higher }\end{array}$ & 100 & - \\
\hline PZ1 & $1 \mathrm{a}$ & $\mathrm{S}$ & low & 5 & & - & very low & $<50$ & - \\
\hline LVh1 & $1-2 a b$ & $\begin{array}{c}\mathrm{S} 12 / \\
(\mathrm{Lu}, \mathrm{Ltu})\end{array}$ & medium & 6.1 & $4.9-7.9$ & - & $\begin{array}{c}\text { very low - } \\
\text { low }\end{array}$ & 90 & (*) \\
\hline CMeg1 & $1-2 a b$ & Ls2,Us, & $\begin{array}{c}\text { medium - } \\
\text { high }\end{array}$ & 6.6 & $6-7.3$ & (*) & $\begin{array}{c}\begin{array}{c}\text { medium or } \\
\text { higher }\end{array} \\
\end{array}$ & 100 & (*) \\
\hline CMec1 & $2 a$ & Ls2 & $\begin{array}{l}\text { medium- } \\
\text {-high }\end{array}$ & 5.8 & & $(* *)$ & $\begin{array}{c}\text { medium or } \\
\text { higher }\end{array}$ & 100 & (*) \\
\hline ARg1 & $1 \mathrm{a}$ & $\mathrm{S},(\mathrm{S} 13)$ & low & 5.3 & & - & & $<100$ & - \\
\hline GLe1 & $2 b$ & Ls2-Ltu & medium & 6 & $5.7-6.2$ & $(*)$ & $\begin{array}{c}\text { medium or } \\
\text { higher }\end{array}$ & 100 & (*) \\
\hline
\end{tabular}

1 see FAO, 1988.

2 see Ag Bondenkunde, 1982. Dominating texture is presented first. Textures in brackets occur seldom. Extremely different texture of the subsurface horizons is separated by a slash.

$3<50 \mathrm{~mm}$ very low; 50 - $90 \mathrm{~mm}$ low; 90 - $140 \mathrm{~mm}$ medium; 140 - $200 \mathrm{~mm}$ high, > $200 \mathrm{~mm}$ very high (AG BONDENKUNDE, 1982).

$4 \mathrm{pH}(\mathrm{KCl})$

$5 *<2 \% ; * * 2-25 \% ; * * *>25 \%$. Values occuring occasionally in brackets

6 includes soluable salts.

combination of AWCr and CEC, and limitations due to erosion, hydromorphy and shallow soils. For certain questions it is possible to get very detailed information from the maps; this is very difficult, though, and in many cases not satisfactory.

One reason is the classification, which is used. It was established mainly by 
CARDOSO (1965) and follows the US soil taxonomy. In this classification soil colours are of overriding importance compared to e.g. texture or contents of free carbonates. This leads to the fact that soils similar in ecological characteristics and closely related to each other are shown in different units. The presented level, the family, is defined by the parent material. As this varies widely in this area, the map is very detailed without increasing expressiveness very much.

On the other hand some soil families of great ecological importance for the characterization of several units were supplemented later to the Portuguese classification (CARDOSO, 1974) and are missing in this map, e.g. the Solos Mólicos - Rendzinas (Rendzic Leptosols and Cambisols) or Solos Litólicos Não Húmicos Pouco Insaturados Para-Solos Calcários (Soils on totally decalcified calcareous sandstone or comparable parent material). These soils had to be added to other units by the authors which resulted in some vagueness.

The greatest disadvantage is that the processes of erosion and colluviation which dominate the soil formation in the Parque are not adequately taken into account. Consequently, parts of the map, especially in the serras, do not show the present soil but the previous one that has now been transformed by processes of colluviation and accumulation. This is the case for instance of the Solos Mediterrâneos Vermelhos ou Amarelos, the Portuguese equivalent of Chromic Luvisols. The same region shows another disadvantage of the map. Because the map was made especially for agricultural purposes, units in areas which are unsuitable for cultivation are very broad and do not show ecological differentiations.

Moreover, hydromorphic properties are often missing or underestimated or on the contrary mentioned where the soils do not show them.

\section{Correlation of the Soil Map 38-B with FAO Units}

The soil units of the Parque which are represented on the map are rather small apart from those along the coast. A map that intends optimal representation of the reality must be very detailed. In contrast here the attempt is made to work out broader units with soils of similar ecological properties to make their use easier for non-pedologists. Of course this means that units might contain soils with properties differing partly or even totally from the average. As the soil map 38-B provides detailed pedological data for the whole area, an attemp has been made to correlate it with units of this survey. A general comparison of units of the Portuguese classification with the old FAO classification (1974) is given by CARDOSO (1974). The results of the comparison of the soil units of this survey according to the FAO (1988) and the soil map 38-B are shown in table 6.1 (CARDOSO, 1974). For additional information the number of soil profiles of the four catenae occuring in one unit of 38-B is given as well as location and lithology. The results are disappointing. Although the FAO units are broader, it is only possible to compare them with the Portuguese soil families of sheet 38-B in a few cases. For the comparison with the ecological classes described in chapter 5 results 
are similar. There are various reasons for that problem, some of them result from the facts explained at the beginning of this chapter.

- In the Portuguese soil map units unsuitable for agricultural purposes are too wide. So the unit Arc defined as rock outcrop contains several soil units of Leptosols and Cambisols.

- The family Vcd (Solos Mediterrâneos Vermelhos ou Amarelos) with the phases $d$ (shallow) and $p$ (stony, rudic) dominates in the units of the coastal part of the Parque. As has been explained before, these soils as defined by CARDOSO (1965) can be found only in a few locations. The effects of erosion, colluviation and re-calcification are neglected, although soils derived from translocated soil material are defined in the Portuguese classification. According to the FAO these soils are either Leptosols or Calcaric, Eutric or Chromic Cambisols.

- In the coastal part of the Parque, calcareous soils are more widespread than described in the soil map. In addition, red soils are less common than described, especially along the northern slope of the main ridges.

- Soils on coarse textured calcareous bedrock, like calcareous sandstone, in level parts of the Parque arerepresented as calcareous soils although they are usually totally decalcified and only contain free carbonates if they are eroded.

- For the great area of the hills between the main ridge and the Tertiary cuesta, the most complicated area in terms of pedology, the chosen units of the soil map are less suitable. To provide complete information, soils of little extension with ecological properties differing from the dominant soils are integrated into the same unit. Thus the unit is of little expressiveness. Moreover, survey errors in the soil map 38-B make it very difficult to compare the units in this part of the Parque in general terms.

\section{REFERENCES}

Ag BODENKUNDE (ed.) (1982) - Bodenkundliche Kartieranleitung. 3, Hannover.

AlCOFORADO, M. J. (1981) - Notas sobre a Geomorfologia da Arrábida Oriental. Linha de Acção de Geografia Física, Relatório. N. ${ }^{\circ}$ 12, Centro dos Estudos Geográficos, INIC, Lisboa.

CARDOSO, J.C. (1964) - Genesis and Classification of Mediterranean Soils Occurring in Portugal. $8^{\text {th }}$ International Congress of Soil Science, Bucharest: 517-525.

CARDoso, J.C. (1965) - Os Solos De Portugal 1 - A Sul do Rio Tejo. Lisboa.

CARDOSO, J.C. (1974) - A Classificação dos Solos de Portugal - nova versão. Boletim de Solos do SROA, 17, Lisboa: 14-46

DiN (DeUTSChes InstiTUt FÜR NoRMUNG) E.V. (1973) - DIN 19683, Blatt 2 Bestimmung der Korngrößenzusammensetzung nach Vorbehandlung mit Natriumpyrophosphat.

Ec (Commission OF The European Communities) (ed.) (1985) - Soil Map of the European Communities 1:1 000 000. Luxembourg.

FAO-UNESCO (ed.) (1974) - Soil map of the world, Vol.1, Legend, Paris.

FAO-UNESCO (ed.) (1988) - Soil map of the world, Revised Legend. Rom. 
HARRACH, T. (1990) - Makrogefügemerkmale und Wurzelverteilung als Kriterien zur Beurteilung der Packungsdichte. Giessen, unedited.

InTERNATIONAL SOIL REFERENCE AND INFORMATION CENTER (ed.) (1987) - Procedures for soil analyses. Technical Paper,9 (2), Wageningen.

KAPPEN, H. (1928) - Die Bodenacidität. Berlin.

KuBIENA, W.L. (1953): Bestimmungsbuch und Systematik der Böden Europas. Enke, Stuttgart.

LANDON, J.R. (ed.) (1991) - Booker Tropical Soil Manual. New York.

LEINFELDER, R.C. (1983) - New mapping results on sheet Setúbal. Serv. Geol. Portugal 69(2): 295-324.

PedRo, J.G. (1991): Vegetação e Flora da Arrábida. Colecção Natureza e Paisagem, 10. Serviço Nacional de Parques, Reservas e Conservação da Natureza. Lisboa.

RiBEIRO, O. (1968): Excursão à Arrábida. Finisterra, Revista Portuguesa de Geografia, III (6), Lisboa: 257-273.

SCHRITTENLOCHER, R. (1995): Die Böden der Serra da Arrábida (Portugal) - Bedeutung, Gefährdung und Schutz. Diplomarbeit am Fachbereich Geographie der Universität Marburg.

Serviço Cartográfico Do Exército De Portugal (1963) - Carta Militar de Portugal folha 465 Outão, Lisboa.

Serviço CARtográfico Do Exército De Portugal (1964) - Carta Militar de Portugal folha 464 Sesimbra, Lisboa.

Serviço Cartográfico Do Exército De Portugal (1966) - Carta Militar de Portugal folha 454 Setúbal, Lisboa.

Serviç̧o De Reconhecimento E Ordenamento Agrário (ed.) (1969) - Carta dos Solos de Portugal e Carta de Capacidade de Uso do Solo. 1: 50 000, folha 38-B.

SERVIÇOS GEOLÓGICOS (1964) - Carta Geológica de Portugal 1: 50 000, folha 38-B.

SkOwRONEK, A. (1978) - Untersuchungen zur Terra rossa in E- und S Spanien - ein regionalpedologischer Vergleich. Würzburger Geographische Arbeiten, 47. Würzburg.

U.S. DEPARTMENT OF AGRICUlture (ed.) (1984) - Soil survey laboratory methods and procedures for collecting soil samples. Soil Survey Investigation Report No.1. Soil Conservation Service, Washington D.C. 